\title{
Economics of Yam (Dioscoreaceae Dioscorea) Marketing: New Insights from Bosso Local \\ Government Area of Niger State, Nigeria.
}

\author{
Festus Victor Bekun ${ }^{1}$ \\ Eastern Mediterranean University, Economics Department \\ North Cyprus, Turkey \\ Email: festus.bekun@emu.edu.tr
}

\begin{abstract}
This current study examines the economics of yam marketing in Bosso local government area of Niger State Nigeria, to this end, statistical tools such as descriptive statistics, marketing margin model, and regression analysis procedures was utilized as estimation techniques. The study relies on random sampling technique of selected 80 yam marketers. The motivation for this study, rest on the dominance of yam marketing operation in the study area as well as the need to chart a better and more efficient system of agricultural marketing for yam marketers in the sampled area. The empirical result reveals that an overwhelming majority $(95.1 \%)$ of the marketers were 21-50 years of age with 6 years and above of marketing experience dominating (90\%). However, most of the yam marketers started the business with capital base of $\$ 1,000$ $\$ 20,000$, it was also discovered was that majority (58.8\%) of the marketers were female and within their active age with mean age of 35 years which goes to show that female can contribute to the responsibility of the family. The study also seeks to explore marketer's preference for source of funding either from the formal institutions such as (Banks and Co-operatives) or the informal institutions (from friends or relatives) which is key in the effective and efficient in yam
\end{abstract}

\footnotetext{
${ }^{1}$ Corresponding author: Festus Victor B. ; phone: +905338849745

Email: festus.bekun@emu.edu.tr (Festus Victor B.)

Address: Institute of Graduate Studies and Research Faculty of Business and Economics, Department of Economics, Famagusta, Eastern Mediterranean University, North Cyprus, via Mersin 10, Turkey
} 
marketing. Finally, the study is set out to find out potential constraints to the attainment of the full gains of yam marketing in the study area and offer workable and visible remedy.

Key words: Yam marketing, Ordinary Least squares, Bosso Nigeria.

\section{Introduction}

Yam belong to the family Dioscoreaceae and to the genus Dioscorea which include about 600 species but only 12 species are of economic significance (Coursey, 1967; Ozo et al., 1984). Two species namely D. rotundata and D. alata grown mainly in Africa and Asia make up about $90 \%$ of the world production of yam for consumption. Yam is the preferred food in Tropical Africa, the Caribbean, and Oceania and to a small extent in South-East Asia (Abraham, 1989). Average yam consumption per capital per day is highest in Benin (364 kcal), Cote d'Ivoire (342 kcal), Ghana (296 kcal) and Nigeria (258 kcal). (IITA,2007).

Humanity desires generally over years has not changed, It still anchored on the three basic needs of life namely; food, clothing and shelter (Agboola \& Balcilar, 2012). The provision of food in adequate quantity and quality to everyone goes beyond meeting an obligation to our fellow human beings; it is a contribution to development that can bestow benefits on all (Izuchukwu, 2011; Sertoglu et al., 2017). Recent data shows that, Nigeria among its global competitors ranks as top producer of yam with a total annual output of 31.5 million metric tons (CBN, 2003).Yam activities in Nigeria offer greater producer surplus for farmers and even more economic surplus through the marketing chain ${ }^{2}$. Generally speaking, marketing chain which imposes a major constrain on the supply as well as the demand price has strong impact on food availability; unfortunately the growth in yam marketing activities has not matched the growing

\footnotetext{
${ }^{2}$ For interested readers on the economic importance of efficient yam marketing see J. O. Olukosi; S.U.Isitor and O. O. Moses (2008) Agricultural Marketing and prices (principles and Applications) $3^{\text {rd }}$ edition, Living books series, GU publications, Abuja, FCT pp 141
} 
demand, this has led to Nigeria in recent times experiencing marketing shortage and the few available have become more expensive.

However, yam tuber like other root crops is essentially a starchy or carbohydrate food. It has a principal nutritional function being a source of supply of calories to the body. Today, the total contribution of yam towards feeding the people of West Africa is less than other staples such as cassava, maize and rice, but the food value of yam is still an important one. The yam crop produces some 18 million tones for the people of the "yam zone" in the tropical region of West Africa. (Wilkin,2001; Ikeh et al.,2013). More so, in addition to its nutritional relevance, yam plays an important role in social and religious festivals. In yam growing areas of West Africa, yam is a vital integral part of the cultural heritage for many people.

In the agricultural economics/marketing literature its well establishes that production is meant to create utility for consumers and this is done when what is produced gets to the consumers. It now becomes necessary to identify the sources of the product and the relative importance of the channels through which consumer's satisfaction is met. It's against the aforementioned, that this study seeks to answer the following pertinent salient questions:

1. What are the basic demographic features of yam marketers in Bosso Local Government Area?

2. How best can we describe the supply channels for yam in this area?

3. Based on observed data of our survey, on an average, what is the price margin for yam marketer in this area?

4. What are the constrains for yam marketers in the study area?

Marketing is not just a subject of interest to agricultural economist alone but also to society who will prefer moderate increase in food price or no increase at all (Ehirim et al.,2007). It is 
therefore of paramount importance to determine the appropriate marketing system for agricultural products among which yam is prominent in Bosso Local Government Area of Niger State, Nigeria.

The remainder of this paper follows thus: The next section provides the material and methods (methodology) and subsequently empirical results and discussion and finally ends with concluding remarks and recommendations.

\section{Methodology and Data Source}

The current study was conducted in Bosso local government area of Niger State, Nigeria. It has a population of 147,359 (NPC, 2006). It has a low land type of landscape. A total sample size of 80 respondents was selected comprising of two categories namely: wholesalers and retailers in the marketing of yam. Four (4) markets from the local government area namely Garatu, Maikunkele, Beji and Gwadabe markets were purposively selected for the study because of their prominence in yam marketing. In each market 20 respondents comprising both wholesalers and retailers were randomly chosen, giving a total sample size of 80 .

A questionnaire designed in accordance with the objectives of the study was administered with the help of trained enumerators in each of the locations to both wholesalers and retailers in order to gather the necessary information on various aspects of marketing of yam in the study area. Data on the socio-economic characteristics of the respondents, quantity and prices of yam purchased and sold by wholesalers and retailers as well as storage and transportation costs were collected.

A simple Ordinary Least Square (OLS) regression was employed, using information from

the sample data to estimate the significance of selected variables on marketing margin, the 
dependent variable used to account for the variation in price is marketing margin under this study.

\section{Model Specification}

Marketing margin as defined under this study, in accordance with Olukosi et al., (2007), can be expressed with the formulation below;

$$
\text { Marketting margin }=\frac{\text { prie }- \text { marginal cost }}{\text { price }} \times 100
$$

Modeling the determinants of marketing margin under this scenario requires that we include as much as possible the observable explanatory variables $\left(\mathrm{X}_{\mathrm{i}}\right)$. Therefore, the functional form of this relationship between marketing margin and our observed independent variable follows:

$$
\mathrm{Y}=\mathrm{f}\left(\mathrm{X}_{\mathrm{i}}, \mathrm{D}_{\mathrm{i}}\right)
$$

Where, $\mathrm{X}_{\mathrm{i}}$ denotes the collected information of the observed independent variables namely: Age of respondent ,educational attainment ,household Size: and $\mathrm{D}_{\mathrm{i}}$ represent the binary operator for gender of respondent $(1=$ male, $0=$ female $)$, marital status $(1=$ married, $0=$ otherwise $)$, occupation ( $1=$ yam selling as major occupation, $0=$ otherwise), scale of yam production $(1=$ retailer.0 otherwise).

The econometric form is expressed below

$\log \mathrm{Y}=\alpha+\beta_{\mathrm{i}} \log \left(\mathrm{X}_{\mathrm{i}}\right)+\delta \mathrm{i} \log \left(\mathrm{D}_{\mathrm{i}}\right)+\varepsilon$.

Ho: There is no significant relationship between some selected socio-economic characteristics of the marketers and their level of marketing margin. 


\section{Results and discussion}

The demographic distribution of the social economics characteristics of the respondents according to gender, age, educational attainment, marital status, numbers of years of experience and household size.

Table 1: Demographic Feature of Respondents

\begin{tabular}{|c|c|c|}
\hline & Frequency & Percentage distribution \\
\hline $\begin{array}{l}\text { Sex: } \\
\text { Male } \\
\text { Female } \\
\text { Total }\end{array}$ & $\begin{array}{l}33 \\
47 \\
\mathbf{1 0 0}\end{array}$ & $\begin{array}{l}41.2 \\
58.8 \\
\mathbf{1 0 0}\end{array}$ \\
\hline $\begin{array}{l}\text { Age } \\
\text { 21-30 years } \\
31-40 \text { years } \\
41-50 \text { years } \\
\text { 51- 60years } \\
\text { Total [mean age }=\mathbf{3 5} \text { ] }\end{array}$ & $\begin{array}{l}42 \\
25 \\
9 \\
4 \\
\mathbf{8 0}\end{array}$ & $\begin{array}{l}52.5 \\
31.3 \\
11.3 \\
5.0 \\
\mathbf{1 0 0}\end{array}$ \\
\hline $\begin{array}{l}\text { Education level } \\
\text { No education } \\
\text { Primary education } \\
\text { Secondary education } \\
\text { Quranic education } \\
\text { Adult education } \\
\text { Total }\end{array}$ & $\begin{array}{l}36 \\
18 \\
21 \\
1 \\
4 \\
\mathbf{8 0}\end{array}$ & $\begin{array}{l}45.0 \\
22.5 \\
26.3 \\
1.3 \\
5 \\
\mathbf{1 0 0}\end{array}$ \\
\hline $\begin{array}{l}\text { Years of experience } \\
1-5 \\
6-10 \\
11-15 \\
16-20 \\
20 \text { years above } \\
\quad \text { Total [mean =32] }\end{array}$ & $\begin{array}{l}8 \\
11 \\
19 \\
28 \\
14 \\
80\end{array}$ & $\begin{array}{l}10.0 \\
13.8 \\
23.8 \\
35.0 \\
17.5 \\
\mathbf{1 0 0}\end{array}$ \\
\hline $\begin{array}{l}\text { Marital Status } \\
\text { Single } \\
\text { Married } \\
\text { Divorce } \\
\text { Window } \\
\text { Total } \\
\end{array}$ & $\begin{array}{l}15 \\
61 \\
3 \\
1 \\
\mathbf{8 0} \\
\end{array}$ & $\begin{array}{l}18.8 \\
76.3 \\
3.8 \\
1.3 \\
\mathbf{1 0 0} \\
\end{array}$ \\
\hline 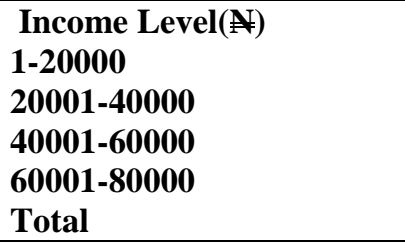 & $\begin{array}{l}2 \\
38 \\
32 \\
8 \\
\mathbf{8 0} \\
\end{array}$ & $\begin{array}{l}2.5 \\
47.5 \\
40.0 \\
10.0 \\
\mathbf{1 0 0} \\
\end{array}$ \\
\hline
\end{tabular}

Source: Authors Computation based on field survey 


\section{Marketing Channel}

Marketing channel this is the route (path) through which commodity or products passes till its gets to the end user (consumer).

Fig 1: Marketing channel for yam in Bosso Local Government Area.

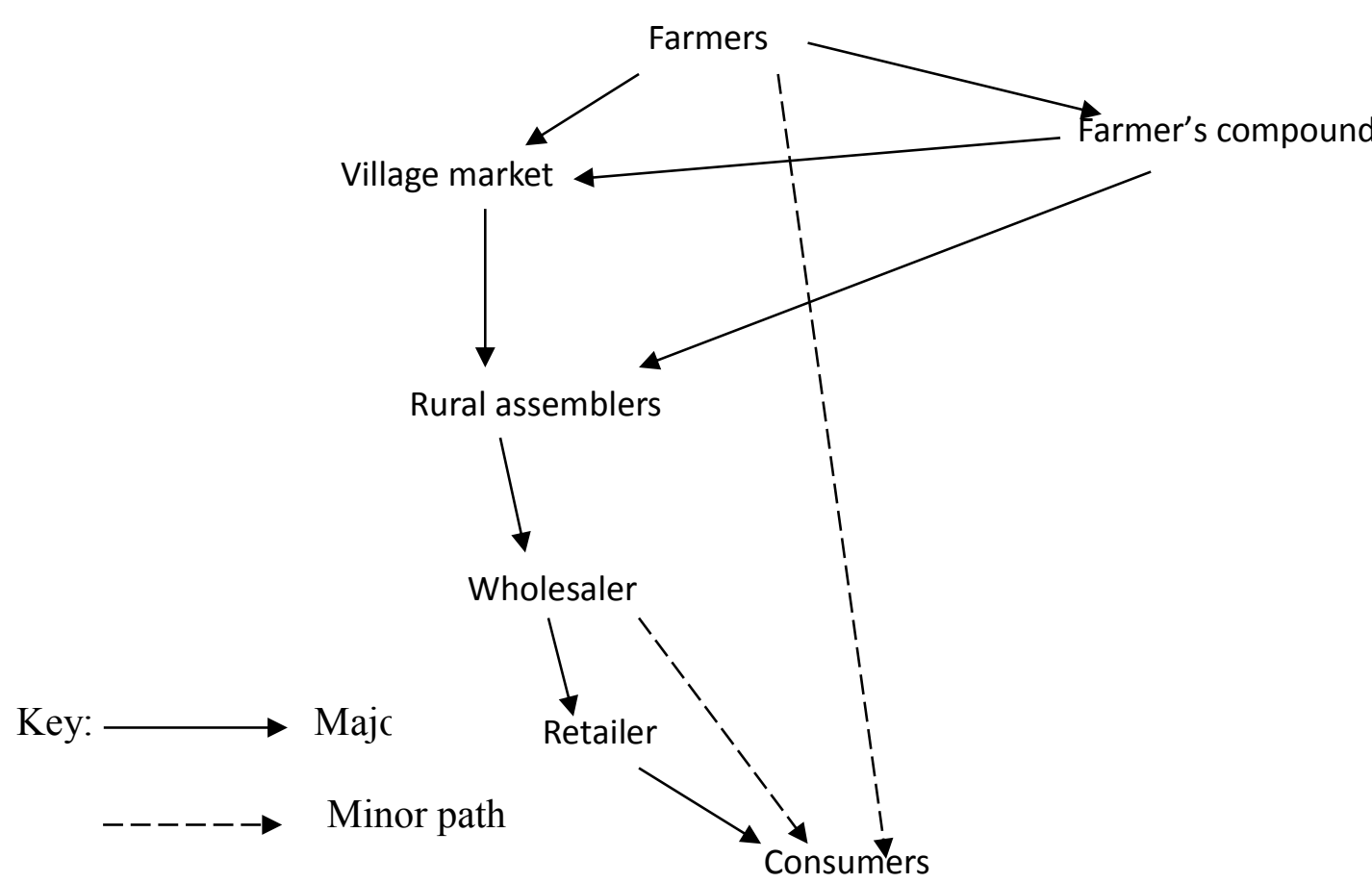

Fig 1: Above reveals that apart from th e of yam from farmers to village market or the farmers compound, other interaction do exist where the wholesalers and retailers form an important group of intermediaries handling where wholesalers and retailers directly buy from the farmers of less importance is buying of yams by consumers directly from the farmer and wholesaler. From assembler, also the handling of yams by retailer directly from assemblers is important of yam in the study area. 
Table 2: The Regression Analysis

\begin{tabular}{|l|l|}
\hline Explanatory variable & Co efficient \\
\hline Constant & $12.1345^{* * *}$ \\
& $(18.62)$ \\
\hline Age & $-0.4398^{* * *}$ \\
& $(-2.87)$ \\
\hline Educational attainment & $-0.1728^{*}$ \\
& $(-1.79)$ \\
\hline Household size & $0.1843^{* * *}$ \\
& $(2.78)$ \\
\hline Gender & 0.0119 \\
& $(0.11)$ \\
\hline Marital status & $-0.4204^{* *}$ \\
& $(-2.11)$ \\
\hline Occupation & $0.2163^{*}$ \\
& $(1.96)$ \\
\hline Quantity of yam handled & 0.0219 \\
& $(0.52)$ \\
\hline $\mathrm{R}^{2}$ & 0.6355 \\
\hline Adjusted $\mathrm{R}^{2}$ & 0.6709 \\
\hline F-Statistic & $3.16^{* * *}$ \\
\hline
\end{tabular}

Note: Results shown in parentheses are absolute value of the t-statistics $* * * * *$ and * implying

rejection of the null at $1 \%, 5 \%$ and $10 \%$ level of significant level respectively. The regression was carried by STATA software.

Double log was chosen as the leading equation on the basis of coefficient of determination $\left(\mathrm{R}^{2}\right)$ value, $\mathrm{T}$ - value- as well as the signs on estimated parameters. The result gave an $\mathrm{R}^{2}$ of $0.635 \%$. This implies that $63.5 \%$ of variation in marketing margin of yam production was explained by the variables included in the model while $36.5 \%$ are left unexplained by the choice model. However, the model depicts high explanatory power of the variation in marketing margin as explained by the explanatory variables.

The co-efficient of age and household were significant at $(\mathrm{P}<0.01)$, Educational attainment and occupation were significant at $(\mathrm{P}<0.10)$ also marital status was significant at $(\mathrm{P}<0.05)$ while the co-efficient of sex, and quantity of yam handled were positive but not significant indicating these variable do not contributes to marketing margin of the farmers. The 
F-statistics was statistically significant at $(\mathrm{P}<0.01)$ which indicates the joint significant of all variables in the model as well as robustness of our model that is, the independent variable adequately explained the dependent variable. The co-efficient with positive signs indicates that an increase in the level of these variables would leads to an increase in marketing margin of the respondent ceteris paribus. The co-efficient age, marital status and educational level had negative sign implied that an increase in this inputs would lead to a decrease in the level of marketing margin. This implies that large family size contributes to marketing margin and also a good pay job (occupation) alongside with yam marketing will have a significant increase in the marketing margin.

Table 3: Distribution of Respondents According to Problem Faced in Yam Marketing Problem Frequency Percentage (\%)

Transportation problem

High rate of spoilage

High fuel cost

High storage cost

Lack of constant supply of yam

Low channel

Theft

Lack of space for storage
47

38

21

39

12

43

69

28

$297 *$
58.8

47.5

26.3

15.0

53.8

86.8

35.0

Total

372*

Source: Authors Computation based on field survey while * denotes multiple response.

The result reveals that theft $(86.8 \%)$ was the most the most serious problem encounter by

farmers in the study area. This problem therefore ranked first among the problems of yam marketing, this goes to show that theft is a major constrain that hampers full attainment of yam marketing in the study area and the implication of this, is that this could discourage young and aspiring marketers that will want to venture into the business in the study area, this could be cub 
with adequate and affordable security personnel stationed in the various markets, Transportation ranked second to theft as a major restrain to yam marketing and the implication of this is that the yam might not get to the end user as at when due which is one of the utility of production, closely followed is low channel which could lead to an increase in the margin of yam, and in the long run lead to low patronage because consumer will obey the law of demand which state that the lower the price the higher the demand ceteris paribus, while high rate of spoilage accounted for $(47.5 \%)$ ranking $5^{\text {th }}$ in the constrains of yam marketing and this can discourage the involvement in the participation in yam marketing.

\section{Concluding remarks and recommendations}

An attempt to investigate the marketing system of yam in Bosso local government area of Niger state, Nigeria was the principal focus of this paper. The study explores the activities of the traders in the marketing of yam in the chosen area of study. To this end, the study sampled 80 respondents in two strata with 4 chosen markets. The estimation techniques employed in this research paper are ordinary least square (OLS) descriptive statistics; marketing margin model. The study's simulations reveals that female were more involved in marketing activities accounting for $(58.8 \%)$ while $41.2 \%$ were male, this goes to show that women involved in yam marketing can have income to support their husband in the family responsibility, the study also showed that (52.5\%) of the respondents were within the age group of 21-30 years and were in their active age not left out (45.0\%) of the respondent had no formal education while $53.8 \%$ of the trader had formal education depicting a reasonable level of literacy among the traders. Majority of the traders had enough capital (income) above $¥ 20,000$, these findings resonates with works of (Aidoo et al.,2012) in Ghana. This implies that $\$ 20,000$ is reasonable enough to start the marketing of yam in the study area. Finally, the study revealed fairly high and positive 
margins in yam marketing activities in Bosso local government Area, suggesting that marketing of yam in the study area is a profitable venture if the bottle neck associate with marketing of yam in the study area is adequately addressed. This means improvements in the marketing functions performed could enhanced improvement in the income levels of the market participants (traders).

\section{Recommendations}

The marketing problems that exist in Bosso local government area of Niger State Nigeria, as revealed by the study conducted in the area shows the existence of imperfection in the marketing system of yam. These imperfections have been known to be the main factors responsible for ineffective marketing of yam in the research area. To reduce or completely eradicate problems associated with yam marketing in the study area, the following recommendations were proposed namely: Provision of transportation facilities, Provision of credit facilities with little interest rate Provision of storage facilities, and Provision of effective information dissemination process.

\section{References}

- Abraham, K., Nair, S. G., \& Sreekumari, M. T. (1989). White yam, Dioscorea rotundata Poir., dwarf type. Tropical Agriculture (Trinidad and Tobago). 66:184-186.

- Agboola, M. O., \& Balcilar, M. (2012). Impact of food security on urban poverty: a case study of Lagos State, Nigeria. Procedia-social and behavioral sciences, 62:1225-1229.

- Aidoo, R., Nimoh, F., Bakang, J. E. A., Ohene-Yankyera, K., Fialor, S. C., Mensah, J. O., \& Abaidoo, R. C. (2012). Estimation of margins and efficiency in the Ghanaian yam marketing chain. Asian Journal of Agriculture and Rural Development, 2(2): 226-234.

- Asiedu, R., \& Sartie, A. (2010). Crops that feed the world 1. Yams. Food Security, 2(4), 305-315.

- Central Bank of Nigeria (Statistical Bulletin) Vol. 14, December 2003 
- Coursey DG (1967) Yams. Longmans, London, pp. 230

- Ehirim, N. C., Onyemauwa, C. S., Ikheloa, E., \& Umezurumba, I. E. (2007). Economics of yam marketing in Umuahia, Abia state, Nigeria. International Journal of Tropical Agriculture and Food Systems, 1(1): 51-56.

- Ikeh, A. O., Ndaeyo, N. U., Akpan, E. A., Udoh, E. I., \& Akata, O. R. (2013). Evaluation of complementary use of organic manure for sustainable water yam production in Uyo, southeastern Nigeria. American Journal of Research Communication, 1(2): 33-48.

- International Institute of tropical Agriculture (IITA): (2007). Yam holding in Southern Nigeria. Economics assessment of problems and trends: available at http://oldlrinternet.iita.org/2007-bulletins

- Izuchukwu, O. (2011), Analysis of the contribution of agricultural sector on the Nigerian economic development. World Review of Business Research, 1(1): 191-200.

- J. O. Olukosi; S.U.Isitor and O. O. Moses (2007) Agricultural Marketing and prices (principles and Applications) 3rd edition, Living books series, GU publications, Abuja, FCT pp. 141

- NPC, (2006) National Population Commission. Provisional Census figure, Federal Government of Nigeria. Niger State Agricultural Development Project (2007) an insight into agricultural activities in Niger State Ministry of Agriculture and National Resources 2007 edition.

- Ozo, O. N., Caygill, J. C., \& Coursey, D. G. (1984). Phenolics of five yam (Dioscorea) species. Phytochemistry, 23(2): 329-331. 
- Sertoglu, K., Ugural, S., \& Bekun, F. V. (2017). The Contribution of Agricultural Sector on Economic Growth of Nigeria. International Journal of Economics and Financial Issues, 7(1): 547-552.

- Wilkin P (2001) Dioscoreaceae of South-Central Africa. Kew Bull 56:361-404 